\title{
Slope Stability Assessment in Semarang Clay: Case Study in Simongan Landslide 2016
}

\author{
${ }^{1}$ Untoro Nugroho, ${ }^{2}$ Haryati Awang, ${ }^{1}$ Rini Kusumawardani and ${ }^{1}$ Tika Ratnasari \\ ${ }^{1}$ Department of Civil Engineering, Universitas Negeri Semarang, Jawa Tengah, Indonesia \\ ${ }^{2}$ Faculty of Civil Engineering, Universiti Teknologi MARA, Shah Alam, Malaysia
}

\begin{abstract}
Indonesia is one of the tropical countries located on the equator which has high and sometimes tendency to be extreme rainfall characteristic. Average rainfall in all regions of Indonesia ranges from 3000-3500 $\mathrm{mm}$ per year. This phenomenon causes Indonesia become a landslide prone country. Several cases of landslides have occurred in the Semarang city, especially in Simongan area. Almost every year a landslide occurs in Simongan area and it always causes a lot of losses. The purposes from this study was to figure out the geotechnical properties of soil and conduct field investigation on the triggers of landslide and mechanism of landslide analysis in the study area. In the area, the soil was composed of silt and clay. To complete all data used in the analysis, field and laboratory testing were conducted.
\end{abstract}

Key words: Landslide, slope stability, clay, Simongan, phenomenon, mechanism

\section{INTRODUCTION}

Indonesia as a country located near the equator line. The tropical climate with a high rainfall intensity is the unique factor which contributes to a landslide hazards in mountainous and hilly area. The effect of extreme climate has induced torrential rainfall and landslide disasters world-wide recently. The rainfall thresholds for triggering shallow landslides have been well discussed and determined in the past decade (Chen et al., 2006; Guzzetti et al., 2007; Wu et al., 201 5, Kumar et al., 2017; Kusumawardani et al., 2016). In Indonesia, a landslide hazard is mostly caused by the influence of high rainfall intensity or earthquake. Rainfall intensity in Indonesia reached 2000-3000 mm annually and as a result of the sediment-related disasters in the mountainous areas. During 2016, the total of landslide in Indonesia reached 600 evidences and this data increase yearly in the past decade. An analysis of slope failure has Considered the rainfall characteristics since, it is supposed as one of triggering factors in the previous study (Matlan et al., 2010; Mukhlisin et al., 2015). Recently, the study about antecedent rainfall increases progressively to obtain the comprehensive results of slope failure behaviour (Bittelli et al., 2012, Mukhlisin et al., 2015). Potential landslide on a slope on is generally studied only partially. This partial studies produce less accurate results because in general landslides occur in a vast area. In this study, some of the parameters which triggered the landslide were analysed in detail to give a comprehensive result on landslide potential in the location of the study.
In Indonesia, Semarang is one of the cities which begins to grow rapidly. As a part of development of Semarang city, in some rural area, man made slope was formed by ground excavation activity. This is an effort to meet the needs of rural housing and infrastructure development which is required to develop the city. The steep man made slopes were found in many residential areas which is a barrier between luxury residential areas and village houses. The majority this area was dominated by sand stone, breccia and thin up to thick clay zone. In some landslide hazards, it was found that they happened at the shallow slope angle. This phenomenon disproves the assumption of a steep angle as the main factors which contribute to this disaster (Paul and Mahajan, 1999; Toeman et al., 2004). The aim of this study was to determine the geotechnical properties of soil in the study area and also investigate the slope stability using numerical methods as back analysis in addition, the analysis of landslide behaviour can be predicted in the future by using this method. The findings are recommendations for the possible counter measure of mitigation systems in the landslide-prone area.

\section{MATERIALS AND METHODS}

Study area: The area which was reviewed as a study area was based on the recapitulation of landslide occurrences which happened in the Semarang city. Simongan area is one of the landslide-prone areas. Almost every year the landslide always happens and a lot of losses are incurred. The condition of the slope of the study has a slope of

Corresponding Author: Rini Kusumawardani, Department of Civil Engineering, Universitas Negeri Semarang, Jawa Tengah, Indonesia 

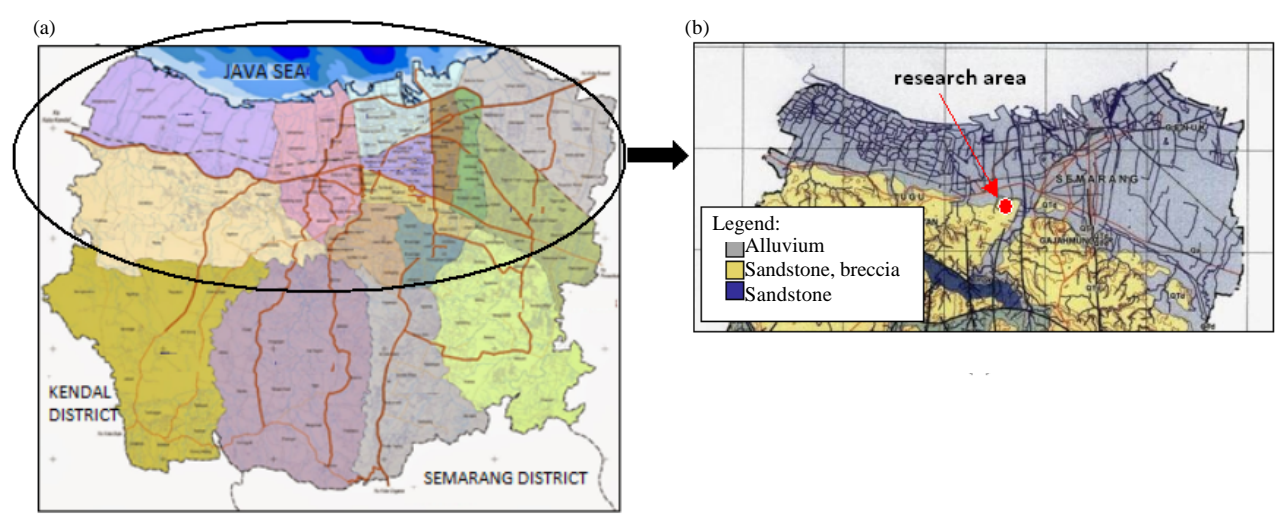

Fig. 1a, b: Location and geologic map of research area

\begin{tabular}{lll}
\multicolumn{2}{l}{ Table 1: Impact of landslide incident in Simongan area } \\
\hline Date & Casualties & Loss properties \\
\hline 16.02 .2002 & 8 killed & Collapse 7 house \\
07.04 .2002 & - & Collapse 4 house \\
08.02 .2009 & 1 killed & Collapse 1 house \\
08.04 .2011 & - & Collapse 1 house \\
19.06 .2013 & 1 killed & Collapse 1 house \\
03.03 .2014 & 1 injured & \\
16.11 .2016 & - & Damage of road \\
\hline
\end{tabular}

about $60^{\circ}$ with a slope length of about $5 \mathrm{~m}$ and a height of $17 \mathrm{~m}$. Similarly, the land around the slopes is functioned and used as densely populated residential area. The location and geologic map of research is shown in Fig. 1. The landslide cases have detrimental impacts such as damage to residence, displaced residents and human casualties. In addition, rainfall data in this area is very complete because it uses automatic tools with high accuracy and accuracy. The occurrence of landslides and their losses in the study area can be seen in Table 1. In the end of 2016, the disaster was destroy a road which relay a habitant house to the main road. The destruction could be seen in Fig. 2.

Geology and geomorphology Semarang city: The North area of Semarang city was dominated by thick alluvium until $70 \mathrm{~m}$ depth. Furthermore, the South area was dominated by volcanic breccia which could be found from North to South of Semarang (Fig. 2). It was formed from Ungaran volcano eruption in past century. The slope of the mountainous and hilly area was almost $2-40 \%$ and the altitude was 90-200 m above sea level. The sediment sea fasies tertiary was found at the middle part of Semarang (Tinjomoyo and Kalialang). Highly consolidated sediment which consisted of volcanic sandstone, breccia and conglomerate and volcanic breccia was found alongside of Garang and Kripik River. The alluvial sediment was composed of gravel, sand, silt, sandy silt and clay.

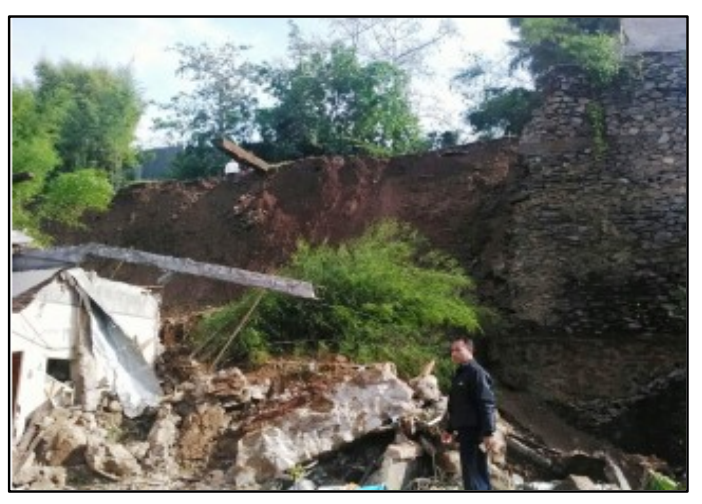

Fig. 2: Landslide occurrences at Semarang city in 2016

Field study and laboratory testing: Field testing showed that at the location of study tended to be composed of clay and silt. The landslide occurred in the area of RT.07/RW.04 Ngemplak Simongan village, District Ngaliyan. The maximum depth of landslide along the landslide field ranged from $0.5-1.5 \mathrm{~m}$. The landslide fields were circular. During the boring to a depth of $5 \mathrm{~m}$ below the ground surface, any water level has not been found. Residual soils which experienced landslide were fully saturated. Testing in the laboratory was conducted for several times to determine the physical properties of soil characteristics, it consisted of testing the distribution of grains, atterberg limit, water content and porosity. The disturbed soil testing which was conducted to determine the distribution of grains employed a combination of sieve analysis and hydrometer method. The purpose of laboratory testing was to obtain soul classification based on unified. Test results can be seen in Table 2 .

Landslide analysis: There were several methods used as the basis for the landslide analysis. Generally, the slope stability was analysed by the equilibrium limit method introduced by bishop. This method was very easy and 
Table 2: Phy sical characteristics of soil sample

\begin{tabular}{lrrc}
\hline Parameters & BH 1 & BH 2 & BH 3 units (\%) \\
\hline Water content (\%) & 15.20 & 13.07 & 12.91 \\
Void ratio (e) & 0.70 & 0.79 & 0.63 \\
Specific gravity & 2.66 & 2.67 & 2.67 \\
Saturation (Sr) & 87.17 & 92.11 & 89.08 \\
Porosity (n) & 41.31 & 44.11 & 38.80 \\
Cohesion (c) & 17.00 & 21.00 & 18.00 \\
\hline
\end{tabular}

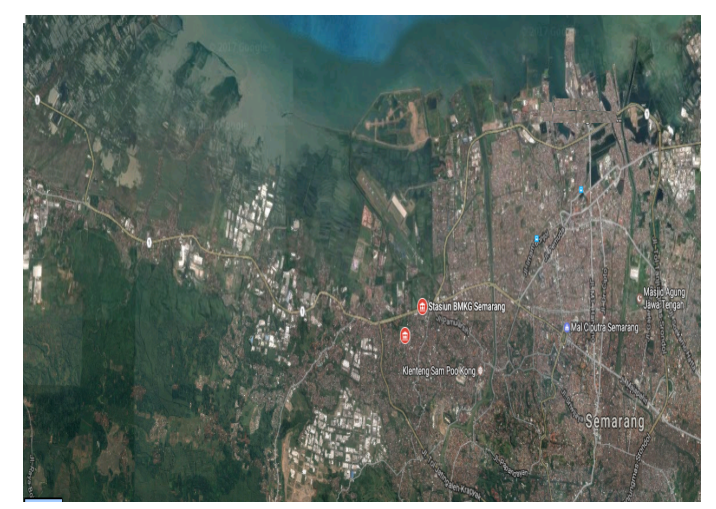

Fig. 3: Location on rainfall station

simple because it was able to determine a direct measure of stability such as the Factor of Safety (FS) directly. The parameter required to be known as input on this method was additional information about the shear strength of soil parameter. The disadvantage of this method was that by using this method the Factor of Safety (FS) is not very accurate even though it can be used as the initial calculation. This is because the value of soil parameters is minimal.

Another method commonly used by researchers these days was the finite element method. In this method, the slope that was analysed was divided into small elements, so, the results become more accurate. Soil strength parameter, soil permeability, soil stiffened, poisson ratio and also detailed of construction stage if needed was required for parameter input. The presence of groundwater is also of great concern when using this method. Phereatic level behavior in soil structure affected on detailed calculation of slope analysis using this method.

Rainfall data and analysis: The rain data used in this study were taken from BMKG station Semarang and Simongan. Rain data were collected at this station because it was close to the location of the study. Rainfall data were taken during the period 2005-2015 with the aim of obtaining comprehensive results. The location of the rainfall station can be seen in Fig. 3. Rainfall data were used as an input parameter in the analysis of slope stability using finite element method. The behavior of rainwater infiltration into the soil layer had to be taken into account when conducting the analysis. The infiltration which permeated into the soil adjusted itself to the soil permeability properties. The depth of rainwater that permeated the soil could generally reach up to a depth of $100 \mathrm{~cm}$ below the soil surface. The longer it rained, the more water infiltrated to the soil.

\section{RESULTS AND DISCUSSION}

Soil physical characteristics: A series of laboratory testing which was conducted respectively in this study was water content, grain size analysis, triaxial and direct shear test. The result of soil physical characteristic test can be seen in Table 2 and the result of grain size distribution test can be seen in Fig. 4 .

The test results showed that the water content in the study area ranged from $12.91-15.20 \%$, the porosity value ranged from $38.80-44.11 \%$ and the void ratio ranged from $0.63-0.70$. The results showed that in the non-rainy conditions, the soil had a high water content. The presence of water that filled the cavities in the soil, had a major impact on the soil, especially on soils that had high shrinkage such as clay soils. Parameters of porosity and void ratio also have high score because the frictional force between the soil particles was small. In accepting a working load, the soil relied on the internal force derived from the friction between the soil grains. If the soil had only a small frictional force, then it would be difficult of the soil to with stand shear forces which then resulted in collapse on the slopes. The score of LL, PL and LL consecutively were as follows $42.70-50.75,27.56-32.46$ and $15.14-18.29 \%$. The results of the analysis of soil classification based on Unified Classsied Classification System (USCS) showed that the soil at the location of the study was considered as $\mathrm{ML}$ (inorganic silt and very fine sand, rocks, argillaceous fine sand or with low silt plasticity).

Slope analysis: Back analysis of landslide analysis in location of the study were conducted using numerical element method PLAXIS. This method was aimed at determining the safety of the slope before and as soon as it was given ground reinforcement. As it is known that the conditions on the slope, it had a soft soil layer with a slope of about $60^{\circ}$ and a height of $17 \mathrm{~m}$. In this study, back analysis was performed by using PLAXIS modeling to figure out the slope stability in the area by using parameter data which have been obtained from literature study and soil sample test in field or in laboratory. Generally the input parameter used in the analysis can be seen in Table 3.

The load on the ground given the burden of residential population around the slopes of $-8.5 \mathrm{kN} / \mathrm{m}^{2}$ in the negative direction indicates the burden of work on the way down. This assumption is adapted to the existing 
conditions in the field where the houses of residents lined up close to the slopes at the study site. Illustration of existing slopes can be seen in Fig. 5a. The result of slope analysis using PLAXIS can be seen in Fig. 5. In Fig. 5b mention that total soil displacement was $26.68 \mathrm{~m}$ which

Table 3: Physical characteristics of soil sample

\begin{tabular}{lllll}
\hline \multicolumn{5}{c}{ Soil layer } \\
Parameter & Symbol & Layer 1 & Layer 2 & Layer 3 (units) \\
\hline Material model & Model & Coulomb & Coulomb & Coulomb \\
Type of material & Type & Undrained Undrained & Undrained \\
Saturated soil weight & $\gamma_{\text {sat }}$ & 20.030 & 20.710 & $20.490 \mathrm{kN} / \mathrm{m}^{3}$ \\
volume & & & & \\
Dry soil weight volume & $\gamma_{\text {unsat }}$ & 18.89 & 19.72 & $19.31 \mathrm{kN} / \mathrm{m}^{3}$ \\
Young modulus & $\mathrm{E}^{\prime}$ & 20,000 & 20,000 & $20,000 \mathrm{~N} / \mathrm{m}^{2}$ \\
Poisson ratio & $U^{\prime}$ & 0.3 & 0.3 & 0.3 \\
Cohesion & $\mathrm{c}$ & 18.338 & 18.338 & $18.338 \mathrm{kPa}$ \\
Soil friction angle & $\varphi$ & 15.186 & 15.186 & 15.186 \\
\hline
\end{tabular}

remarks in red colour zone and it dominantly occurred in $\mathrm{x}$ direction. The value of total displacement was

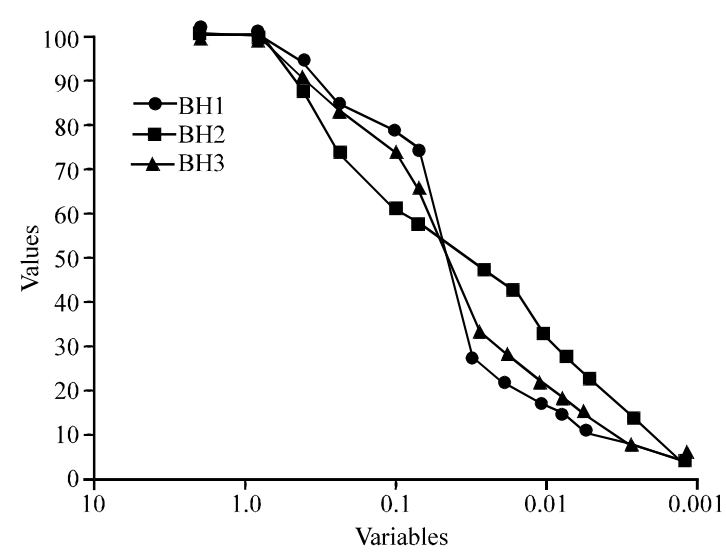

Fig. 4: Soil distribution analysis
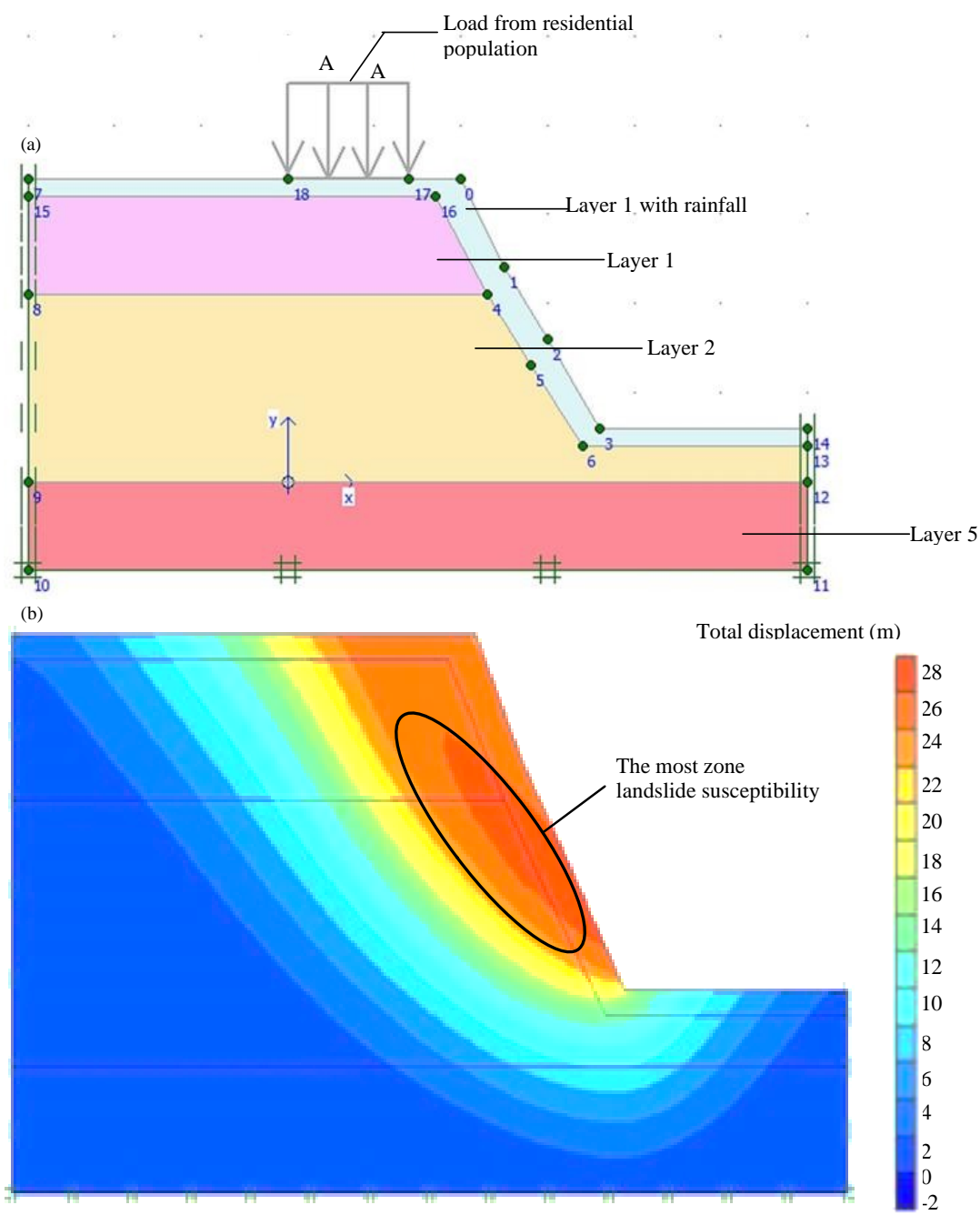

Fig. 5a, b: Deformation analysis of slope existing 

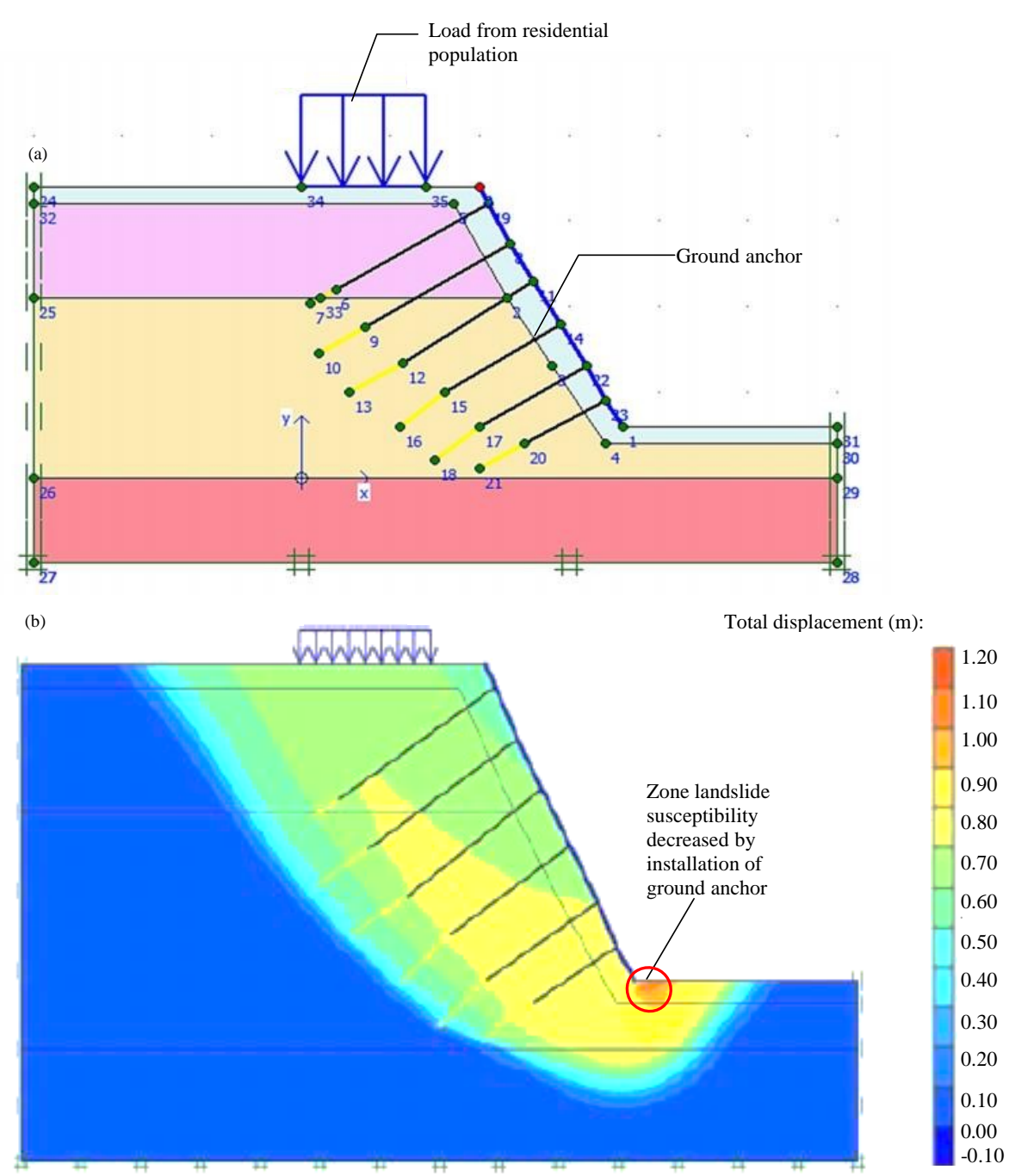

Fig. 6a, b: Soil reinforcement in slope analysis design

decreasing more farther the distance from slope. Safety factor was 0.89 . These results indicated that the slope of the study area was susceptible to the potential for landslide hazard because the $\mathrm{SF}$ value was $<1$.

Soil reinforcement: Soil reinforcement method as a preventive effort in the analysis was conducted using ground anchor. Anchor was an important part of the structure that transmitted the tensile force from the main structure to the soil around the anchor. The shear strength of the surrounding soil was used for resist the tensile strength of the anchor and to bind the anchor to a suitable ground. Anchor consisted of high-strength steel tendons which were installed at a specific slope angle and at a depth required to resist the existing load. On the slope, ground anchor was used to make the slope stability remain safe from the hazard of ground movement and landslide that occurred. The principle of anchoring is a construction process whereby anchor was inserted into the soil. Once clipped an anchor was usually given a pre-tensile force and on top of which was held by the head anchor. The slope condition which was given soil reinforcement using ground anchor can be seen in Fig. $6 \mathrm{a}$. The results of numerical simulation by using PLAXIS could be seen in Fig. 6b. Numerical analysis using PLAXIS for slope reinforcement using ground anchor showed a deformation and displacement in on the slope stability. The analysis showed a maximum total displacement in $\mathrm{x}$ is $1.20 \mathrm{~m}$. The $\mathrm{SF}$ value was reached 1.044. From this analysis, it could be said that soil reinforcement by installation of ground anchor could improve the value of safety factor of landslide possibility. 


\section{CONCLUSION}

From observation of last landslide, it could be concluding the landslide is shallow. It located in sandstone and breccia area. Based on the particle size distribution data, the material observed in research are dominated by clay and silt with a little sand. The caharacteristic of clay sample has a medium to high plasticity. Direct shear test was conducted soil sample revealed that the shear strength parameter is relative low. The simulation numeris are found the stability of slopes FS of 0.89 for slope exixting and FS of 1.044 of slope reinforcement by utilizing ground anchor. For the value with reinforcement is slightly above the limiting FS value of 1.0 for failed slopes.

\section{REFERENCES}

Bittelli, M., R. Valentino, F. Salvatorelli and P.R. Pisa, 2012. Monitoring soil-water and displacement conditions leading to landslide occurrence in partially saturated clays. Geomorphology, 173: 161-173.

Chen, R.F., K.J. Chang, J. Angelier, Y.C. Chan and B. Deffontaines et al., 2006. Topographical changes revealed by high-resolution airborne LiDAR data: The 1999 tsaoling landslide induced by the Chi-Chi earthquake. Eng. Geol., 88: $160-172$.
Guzzetti, F., S. Peruccacci, M. Rossi and C.P. Stark, 2007. Rainfall thresholds for the initiation of landslides in central and southern Europe. Meteorol. Atmos. Phys., 98: 239-267.

Kumar, M., S. Rana, P.D. Pant and R.C. Patel, 2017. Slope stability analysis of Balia Nala landslide, Kumaun Lesser Himalaya, Nainital, Uttarakhand, India. J. Rock Mech. Geotech. Eng., 9: 150-158.

Kusumawardani, R., T.C. Upomo and M. Faizal, 2016. Back-analysis of hoek-brown criterion: Rock slide case in MANADO. Intl. J. Geomate, 11: 2808-2814.

Matlan, S.J., M.L. Lee and N. Gofar, 2010. Backanalysis of rainfall induced landsides by PERISI model. Proceedings of the International Conference on Geotechnical and Transportation Engineering, December 1-3, 2010 , Universiti Teknologi Malaysia, Kota Kinabalu, Malaysia, pp: 1-5.

Mukhlisin, M., S.J. Matlan, M.J. Ahlan and M.R. Taha, 2015. Analysis of rainfall effect to slope stability in Ulu Klang, Malaysia. J. Technol., 72: 15-21.

Paul, S.K. and A.K. Mahajan, 1999. Malpa rockfall disaster, Kali valley, Kumaun Himalaya. Curr. Sci., 76 : 485-487.

Teoman, M.B., T. Topal and N.S. Isik, 2004. Assessment of slope stability in Ankara clay: A case study along E90 highway. Environ. Geol., 45: 963-977.

Wu, X., X. Chen, F.B. Zhan and S. Hong, 2015. Global research trends in landslides during 1991-2014: A bibliometric analysis. Landslides, 12: 1215-1226. 